\title{
Assessment of Trace Metal Concentrations in Feathers of White-chinned Petrels, Procellaria aequinoctialis, from the Patagonian Shelf
}

\author{
Juan Pablo Seco Pon (Corresponding author) \\ Laboratorio de Vertebrados. Instituto de Investigaciones Marinas y Costeras \\ Facultad de Ciencias Exactas y Naturales, Universidad Nacional de Mar del Plata \\ Funes 3250 (B7602AYJ) Mar del Plata, Argentina \\ - Consejo Nacional de Investigaciones Científicas y Técnicas (CONICET) \\ Av. Rivadavia 1917 (C103AAJ) Buenos Aires, Argentina \\ Tel: 54-223-475-2426 (466) E-mail: secopon@mdp.edu.ar

\section{Ornela Beltrame} \\ Departamento de Biología, Facultad de Ciencias Exactas y Naturales \\ Universidad Nacional de Mar del Plata. Funes 3250 (B7602AYJ) Mar del Plata \\ Provincia de Buenos Aires, Argentina \\ Área Oceanografía Química, Instituto Argentino de Oceanografía (IADO)
}

Florida 4000, Edificio E1, Casilla de Correo 804 (8000) Bahía Blanca, Provincia de Buenos Aires, Argentina

- Consejo Nacional de Investigaciones Científicas y Técnicas (CONICET)

Av. Rivadavia 1917 (C103AAJ) Buenos Aires, Argentina

Jorge Marcovecchio

Área Oceanografía Química, Instituto Argentino de Oceanografía (IADO)

Florida 4000, Edificio E1, Casilla de Correo 804 (8000) Bahía Blanca, Provincia de Buenos Aires, Argentina

- Consejo Nacional de Investigaciones Científicas y Técnicas (CONICET)

Av. Rivadavia 1917 (C103AAJ) Buenos Aires, Argentina

\section{Marco Favero}

Laboratorio de Vertebrados. Instituto de Investigaciones Marinas y Costeras

Facultad de Ciencias Exactas y Naturales, Universidad Nacional de Mar del Plata

Funes 3250 (B7602AYJ) Mar del Plata, Argentina

- Consejo Nacional de Investigaciones Científicas y Técnicas (CONICET)

Av. Rivadavia 1917 (C103AAJ) Buenos Aires, Argentina

Patricia Gandini

Consejo Nacional de Investigaciones Científicas y Técnicas (CONICET)

Av. Rivadavia 1917 (C103AAJ) Buenos Aires, Argentina

Universidad Nacional de la Patagonia Austral. CIPD Av. Prefectura s/n (9050) Puerto Deseado

Provincia de Santa Cruz, Argentina

Wildlife Conservation Society. Wildlife Conservation Society

2300 Southern Boulevard, 18 Bronx, New York 10460, USA 
Received: September 22, 2011

doi:10.5539/ep.v1n1p29
Accepted: October 17, $2011 \quad$ Published: January 1, 2012

URL: http://dx.doi.org/10.5539/ep.v1n1p29

\begin{abstract}
$\mathrm{Cd}, \mathrm{Cr}, \mathrm{Cu}, \mathrm{Fe}, \mathrm{Ni}, \mathrm{Pb}$, and $\mathrm{Zn}$ were measured in feathers from male and female White-chinned petrels Procelllaria aequinoctialis accidentally killed in longliners off Argentina in 2005. $\mathrm{Cd}, \mathrm{Pb}$, and $\mathrm{Ni}$ concentrations in adult feathers were below detection limits regardless of the birds' sex. Metal concentrations did not vary with sex for $\mathrm{Cu}, \mathrm{Fe}$ and $\mathrm{Zn}$ in feathers of adult birds despite significant differences in body size between males and females. The $\mathrm{Cu}$ and $\mathrm{Fe}$ concentrations differed significantly between the type of feather within individual birds. The mean concentrations of metals determined here were within the range of concentrations reported in feather tissues of other related Procellariiformes species from different biogeographic areas. However, the concentrations of $\mathrm{Cr}$ were similar to those reported for other petrels from polluted areas of the North Pacific. Thus, it appears likely that levels of pollution in Patagonia may not be as negligible as previously thought for some trace metals.
\end{abstract}

Keywords: White-chinned Petrels, Procellaria aequinoctialis, Seabirds, Feather tissues, Trace metals, Pollution monitoring, Patagonian Shelf

\title{
1. Introduction
}

White-chinned petrels, Procellaria aequinoctialis, (WCP) are among the largest of all-dark petrels, only smaller than giant petrels (Onley \& Scofield, 2007). White-chinned petrels breed in dense colonies on a number of widely spaced sub-Antarctic islands (Brooke, 2004). Georgias del Sur/South Georgia has long been considered to hold the largest breeding population of WCPs in the world, with an estimated two million pairs (Prince \& Croxall, 1993). However, a recent survey of the whole archipelago indicates that the size of its breeding population is currently some $40-45 \%$ of the former estimate (Martin et al., 2009). Even so, the area holds more WCPs than all other sites worldwide combined (ACAP, 2011). The majority of Georgias del Sur/South Georgia WCPs exploit waters of the Patagonian Shelf during the non-breeding, pre-laying exodus and incubation periods, and to a lesser extent during chick-rearing when they mainly forage over Georgias del Sur/South Georgia shelf and shelf-slope, around Orcadas del Sur/South Orkney (Berrow et al., 2000; Phillips et al., 2006), and occasionally in the Patagonian Shelf (Mackley et al., 2011).

The Patagonian Shelf is the marine ecosystem off the southern coast of Argentina, an important area of global concern, providing food for at least 700 species of marine vertebrates, some of which come from distant regions (e.g. Antarctica, Australia and New Zealand, Tristan da Cunha) (Arata et al., 2009; Croxall \& Wood, 2002; Favero \& Silva Rodriguez, 2005; Quintana et al., 2009). Although the Patagonian Shelf is often regarded as a relatively uncontaminated region (Barbieri et al., 2007; González-Solís et al., 2002; Stewart et al., 1999), the level of pollution in this vast marine area may not be as negligible as previously thought for some metals (González-Solís et al., 2002; Seco Pon et al., 2011). Additional robust information from the region is needed to understand contaminant concentrations and defining biological indicators in this important marine ecosystem of the Southern Hemisphere (www.lme.noaa.gov).

There have been several studies of contaminants in South Atlantic petrel species, including WCPs (Anderson et al., 2010; Becker et al., 2002; González-Solís et al., 2002; Muirhead \& Furness, 1988; Thompson \& Furness, 1989a, 1989b). White-chinned petrels are ideal indicators of contaminant accumulation in the pelagic marine environment, because they are apex predators, feeding primarily on krill and fish (Croxall et al., 1995) within defined feeding areas relatively close to their breeding grounds (Mackley et al., 2011; Phillips et al., 2006). It should be stressed that most of the studies were conducted in feather tissues and that for some metals (e.g. $\mathrm{Pb}$ and $\mathrm{Hg}$ ) the concentrations in feathers are strongly correlated to the levels in blood (Burger \& Gochfeld, 1990; Monteiro \& Furness, 2001). Accordingly, feather samples have been used extensively for assessing trace metal exposure on several seabird species as a result of some methodological advantages they bring over other tissues (e.g. feathers provide easily obtainable and non-invasive matrices, they also provide retrospective time series analyses, and endangered species can be resample systematically and released without substantial harm) (Burger \& Gochfeld, 2004, 2009; Burger, 1993; Monteiro et al., 1998; Pilastro et al., 1993). This is particularly relevant considering that half of all petrel species are globally threatened with extinction (IUCN BirdLife International, 2010).

In this baseline study, we assessed the concentrations of $\mathrm{Cd}, \mathrm{Cr}, \mathrm{Cu}, \mathrm{Fe}, \mathrm{Pb}, \mathrm{Ni}$, and $\mathrm{Zn}$ in feathers of male and female WCP coming from individuals accidentally captured by commercial longliners operating in the 
Patagonian Shelf off Argentina. We focused on WCPs because: (1) this petrel has a strong interaction with commercial fisheries and as such is the species most often accidentally killed in Argentine waters (Favero, 2008; Seco Pon et al., 2007; among others), and (2) it is classified as "Vulnerable" by the International Union for the Conservation of Nature (IUCN BirdLife International, 2010) and included in Annex I of the Agreement on the Conservation of Albatrosses and Petrels (ACAP, 2011).

\section{Materials and Methods}

\subsection{Sample Collection}

All of the birds examined in this study were accidentally caught by demersal longliners targeting the fish, Kingclip Genypterus blacodes, in waters off the Patagonian Shelf, Argentina during summer 2005 chiefly between $42-47^{\circ} \mathrm{S}$ and $59-63^{\circ} \mathrm{W}$. The fishing gear used by this industry has been described in previous studies (Gandini \& Frere, 2006; Seco Pon et al., 2007). Overall, thirty five adult petrels, without evidence of predation while they had been immersed on the longline, were used in this study. Immediately after collection, petrels were given an identification number, bagged individually, and stored deep frozen and later transferred still frozen $\left(-18{ }^{\circ} \mathrm{C}\right)$ to the Centro de Investigaciones de Puerto Deseado, Santa Cruz Province, Argentina. Biometric measurements of these birds are presented in Appendix A. Sex was determined by visual inspection of gonads in the laboratory. The last grown primary feather (P10) (Warham, 1990) was systematically obtained from the right wing of each sampled individual and a random pinch of feathers was plucked from the right side of the breast of the same individual. Given the difficulty in handling and weighing single feathers, multiple breast feathers were grouped and placed in envelopes. Although there may be some variation in metal concentrations among breast feathers, by using several feathers the differences are averaged (Bond \& Diamond, 2008). Primary feathers were stored apart from breast feathers.

\subsection{Metal Analysis}

Primary 10 and breast feathers were washed vigorously (at least three times) in deionized water alternated with acetone to remove loosely adherent external contamination (Burger et al., 1994) and then dried at $60{ }^{\circ} \mathrm{C}$. All materials associated with trace metal extraction were thoroughly acid-cleaned and rinsed with deionized water before use (Clesceri et al., 1998). Samples were digested in a mixture of concentrated acids, according to methods described by Marcovecchio and Ferrer (2005). About $250 \mathrm{mg}$ were removed from the outermost (distal) segment of each feather and mineralized with a 1:3 perchloric-nitric acid mixture in a thermostatic bath (at $120 \pm$ $10{ }^{\circ} \mathrm{C}$ ) up to minimum volume. Solutions were made up to $10 \mathrm{ml}$ with $0.7 \%$ nitric acid. Each feather segment was sectioned, and each section digested separately to ensure the reproducibility of the method. Element concentrations were determined using a Perkin-Elmer AA-2380 atomic absorption spectrophotometer with air/acetylene flame. Analytical grade reagents were used for the relevant blanks and calibration curves and the analytical quality (AQ) was tested against reference materials (mussel tissue flour, R.M.N ${ }^{\circ}$ ) provided by the National Institute for Environmental Studies (NIES) from Tsukuba (Japan). All elements were analyzed in dry mass tissue. Percentage ranges of recovery in the analysis of reference materials to assess analytical quality were between $91-101 \%$ for all the considered metals. The obtained values from the analysis of the reference materials were within the range of certified ones. The analytical precision expressed as coefficients of variance are $<10 \%$ for all the metals based on replicate analysis. Instrumental detection limits $\left(\mu \mathrm{g} \mathrm{g}^{-1}\right)$ were: $\mathrm{Cd}: 0.20, \mathrm{Cr}: 0.29, \mathrm{Cu}$ : 0.77 , Fe: 2.73 , Ni: $1.54, \mathrm{~Pb}: 1.50$, and $\mathrm{Zn:} 0.88$.

\subsection{Statistical Analysis}

Concentrations of $\mathrm{Cd}$ and $\mathrm{Ni}$, which were below limits of detection (LOD), and concentrations of metals under the LOD in more than $40 \%$ of overall samples were reported in the summary statistics but excluded from further considerations or statistical analyses (Anderson et al., 2010; Seco Pon et al., 2011). For the remaining metals, a few values were under the LOD for some metals (e.g. $22 \%$ for $\mathrm{Cr}$ in breast feathers). To avoid missing values distorting the statistical outcomes, a value equal to one-half the LOD limit for the respective metal was assigned. To analyze the relationship of metal concentrations with type of feather and sex, we employed general linear mixed models (GLMM) with normal error structure and identity link function (Crawley, 2007). This analysis was performed using GLMM to consider the non-independence of the type of feather within an individual bird. The relationship between the metal concentrations and type of feather and sex was modeled with individual identity as a random effect and type of feather and sex as a fixed effect (Crawley, 2007). We also examined the covariation among elements in type of feathers of male and female birds using Pearson correlations. To run the GLMM and the Pearson, data were transformed using $\log _{10}$ (x) when necessary to accomplish assumptions of normality and variance homoscedasticity (Zar, 1999). 
Metal concentrations ( $\mu \mathrm{g} \mathrm{g}^{-1}$ dry mass) are presented as means \pm one SD. Both arithmetic and geometric means are given to facilitate comparisons with other studies in literature. Statistical analysis of the data was performed using R software, Version 2.5.1. (R Development Core Team, 2004). In all cases, we assumed the results were statistically significant when alpha was $\leq 0.05$.

\section{Results}

The mean concentration of $\mathrm{Cd}, \mathrm{Cr}, \mathrm{Cu}, \mathrm{Fe}, \mathrm{Ni}, \mathrm{Pb}$, and $\mathrm{Zn}$ in the last grown primary and breast feathers of WCP is given in Table 1. Concentrations of $\mathrm{Cd}$ and $\mathrm{Ni}$ were below the LOD and concentrations of $\mathrm{Cr}$ and $\mathrm{Pb}$ were under the LOD in more than $40 \%$ of samples.

Using GLMM, no significant interaction was found between feather type and sex for $\mathrm{Cu}, \mathrm{Fe}$, and $\mathrm{Zn}$ concentrations (GLMM, all $\mathrm{P}>0.10$ ). However, the $\mathrm{Cu}$ (GLMM: $F_{1,34}=34.12, P<0.001$ ), and $\mathrm{Fe}$ concentrations (GLMM: $F_{1,34}=40.67, P<0.001$ ) differed significantly among the type of feather within individual WCPs. Breast feathers had significantly higher concentrations of $\mathrm{Cu}$ than primary feathers, whilst primary feathers had significantly higher concentrations of Fe than breast feathers. $\mathrm{Zn}$ concentrations did not differ between individual feather tissues (GLMM: $F_{1,34}=0.41, P=0.52$ ).

Correlations among trace metal concentrations within feather type from birds of a particular sex were in general non significant (Pearson correlations, all $P>0.10$ ). One exception was a significant positive correlation between Fe and Zn concentrations in primary feathers of female WCP (Pearson $r=0.612, P=0.03, n=35$ ).

\section{Discussion}

Some caution should be taken when assessing statistical variability in the biophysical or chemical data, because sample numbers were small and the samples were not collected from the field to a rigorous protocol, but ad libitum from the longline by-catch. Statistically significant differences $(P<0.001)$ were observed for some metals among feather tissues within individual birds. Interestingly, most petrels undertake a simple descendent or variant molt of their primary or flight feathers (Bridge, 2006) but detailed studies of molt in WCPs are scarce. Given that birds are able to eliminate a substantial portion of their body burden of certain trace metals via feather moulting, the concentration of certain metals may vary during this period (Dauwe et al., 2003). Thus comparisons and conclusions in this study are based on breast feathers given that they are known to be the most representative of metal concentrations in plumage (Furness et al., 1986; Burger \& Gochfeld, 2004).

No statistically significant differences were observed between feather type and sex for $\mathrm{Cu}, \mathrm{Fe}$, and $\mathrm{Zn}$ concentrations in petrels. These findings were similar to those of Burger (1993), who found no sex-related differences in metal concentrations in the feathers of seabirds in five out of eight species studied, that were hundreds of kilometers apart. For example, sex was not a significant variable for the same array of metals in feathers of North Pacific (Phoebastria immutabilis; Burger \& Gochfeld, 2000a) and South Atlantic albatrosses (Thalassarche melanophrys; Seco Pon et al., 2011). Interestingly though, few statistically significant body-size differences were observed between WCP sexes (Appendix A). This finding was unexpected considering that metal concentrations were reported to vary in those species with body-size differences between sexes or different diets. Females also have additional routes of ridding the body of metals (i.e. by sequestering metals in the eggshell or transferring metals via the vitellus or albumen) (Bond \& Diamond, 2009; Burger \& Gochfeld, 2009; Burger, 1993; Furness, 1996, Lacoue-Labarthe et al., 2008).

The concentrations of metals determined in this study are, on average, within the range of concentrations reported in the few recent studies on metals in feather tissues of other related species from different biogeographic areas (Table 2). Moreover, the observed metal concentrations in WCPs are well below those considered to cause harmful effects in birds (see Furness, 1996; Lock et al., 1992). Interestingly, the concentrations of some metals, most notably $\mathrm{Cr}$, are similar to those reported for other petrel species from polluted areas of the North Pacific (Burger \& Gochfeld, 2000b). Cr is a non-essential metal that comes from a variety of anthropogenic sources (Eisler, 1986; Towill et al., 1978) and is considered to be potentially toxic to seabirds (Eisler, 1986). Thus, although this study provides essential baseline data for risk assessment modeling of the Patagonian Shelf, it appears likely that (in line with that reported for other species in the same area, Seco Pon et al., 2011) the level of pollution in Patagonia may not be as negligible as previously thought for some trace metals.

\section{Acknowledgments}

Authors would like to thank Dr. Laura Mauco and all the crew of the F/V Argenova XII. One anonymous referee and the editor significantly improved a draft. This work was supported by the Instituto Argentino de Oceanografía, Universidad Nacional de la Patagonia Austral, Universidad Nacional de Mar del Plata, CONICET, 
Wildlife Conservation Society, and the U.S. Fish and Wildlife Service. Special thanks to Julián Crujeiras (Argenova S.A.) for providing accommodations (for JPSP) aboard the Argenova XII.

\section{References}

Agreement on the Conservation of Albatrosses and Petrels (ACAP). (2011). The ACAP Species Assessments. [Online] Available: http://www.acap.aq/acap-species (September 2, 2011).

Anderson, O.R.J., Phillips, R.A., Shore, R.F., McGill, R.A.R., McDonald, R.A., \& Bearhop, S. (2010). Element patterns in albatrosses and petrels: influence of trophic position, foraging range, and prey type. Environmental Pollution, 158, 98-107.

Arata, J., Croxall, J., Huin, N., Nicholls, D., Phillips, R., Quintana, F., Robertson, C.J.R., Robertson, G., Trathan, P., \& Falabella, V. (2009). Parte 2. Albatros. In V. Falabella, C. Campagna, \& J. Croxall (Eds.). Proyecto Modelo del Mar, Argentina (pp. 76-104). Wildlife Conservation Society, Argentina, CONICET, Argentina and BirdLife International, [Online] Available: http://atlas-marpatagonico.org/ (July 8, 2010).

Barbieri, E., Garcia, C.A.B., Passos, E.A., \& Aragão, K.A.S. (2007). Heavy metal concentration in tissues of Puffinus gravis sampled on the Brazilian coast. Ararajuba, 15, 69-72.

Becker, P.H., González-Solís, J., Behrends, B., \& Croxall, J.P. (2002). Feather mercury levels in seabirds at South Georgia: influence of trophic position, sex and age. Marine Ecology Progress Series, 243, 261-269. http://dx.doi.org/10.3354/meps243261

Berrow, S.D., Wood, A.G., \& Prince, P.A. (2000). Foraging location and range of White-chinned Petrels Procellaria aequinoctialis breeding in the South Atlantic. Journal of Avian Biology, 31, 303-311. http://dx.doi.org/10.1034/j.1600-048X.2000.310305.x

BirdLife International. (2011). Species factsheet: Family = Procellariidae (Petrels and shearwaters) [Online] Available:

$\mathrm{http}: / / \mathrm{www} \cdot$ birdlife.org/datazone/speciessearchresults.php?reg $=\& \mathrm{cty}=\& \mathrm{cri}=\& \mathrm{fam}=18 \& \mathrm{gen}=0 \& \mathrm{spc}=\& \mathrm{cmn}=\&$ ha $\mathrm{b}=\& \mathrm{thr}=\& \mathrm{bt}=\& \mathrm{rec}=\mathrm{N} \& \mathrm{vag}=\mathrm{N} \& \mathrm{hdnAction}=\mathrm{ADV} \_$SEARCH\& SearchTerms $=($September 2,2011$)$.

Bond, A.L., \& Diamond, A.W. (2008). High within-individual variation in total mercury concentration in seabird feathers. Environmental Toxicology and Chemistry, 27, 2375-2377. http://dx.doi.org/10.1897/08-163.1

Bond, A.L., \& Diamond, A.W. (2009). Total and methyl mercury concentrations in seabird feathers and eggs. Archives of Environmental Contamination and Toxicology, 56, 286-291. http://dx.doi.org/10.1007/s00244-008-9185-7

Bond, A.L., \& Lavers, J.L. (2010). Trace element concentrations in feathers of Flesh-footed Shearwaters (Puffinus carneipes) from across their breeding range. Archives of Environmental Contamination and Toxicology, 61, 318-326. http://dx.doi.org/10.1007/s00244-010-9605-3

Bridge, E.S. (2006). Influences of morphology and behavior on wing-molt strategies in seabirds. Marine Ornithology, 34, 7-19.

Brooke, M. (2004). Albatrosses and petrels across the world. Oxford: Oxford University Press.

Burger, J., \& Gochfeld, M. (2004). Marine birds as sentinels of environmental pollution. EcoHealth, 1, 263-274. http://dx.doi.org/10.1007/s10393-004-0096-4

Burger, J., \& Gochfeld, M. (2009). Mercury and other metals in feathers of Common Eider Somateria mollissima and Tufted Puffin Fratercula cirrhata from the Aleutian Chain of Alaska. Archives of Environmental Contamination and Toxicology, 56, 596-606. http://dx.doi.org/10.1007/s00244-008-9207-5

Burger, J., \& Gochfeld, M. (2000a). Metals in Laysan Albatrosses from Midway Atoll. Archives of Environmental Contamination and Toxicology, 38, 254-259. http://dx.doi.org/10.1007/s002449910033

Burger, J., \& Gochfeld, M. (2000b). Metals levels in feathers of 12 species of seabirds from Midway Atoll in the northern Pacific Ocean. Science of the Total Environment, 257, 37-52. http://dx.doi.org/10.1016/S0048-9697(00)00496-4

Burger, J., \& Gochfeld, M. (1990). Tissue levels of lead in experimentally exposed Herring Gull (Larus argentatus) chicks. Journal of Toxicology and Environmental Health, 29, 219-233. http://dx.doi.org/10.1080/15287399009531385 
Burger, J., Nisbet, I.C.T., \& Gochfeld, M. (1994). Heavy metal and selenium levels in feathers of known-aged Common terns Sterna hirundo. Archives of Environmental Contamination and Toxicology, 26, $351-355$. http://dx.doi.org/10.1007/BF00203562

Burger, J. (1993). Metals in avian feathers: bioindicators of environmental pollution. Reviews in Environmental Toxicology, 5, 203-311.

Clesceri, L.S., Greenberg, A.E., \& Eaton, A.D. (1998). Standard methods for the examination of water and wastewater. (20th ed.). Washington: Washington American Public Health Association.

Crawley, M.J. (2007). The R book. United Kingdom: Chichester.

Croxall, J.P., Hall, A.J., Hill, H.J., North, A.W., \& Rodhouse, P.G. (1995). The food and feeding ecology of the white-chinned petrel Procellaria aequinoctialis at South Georgia. Journal of Zoology, London, 237, $133-150$. http://dx.doi.org/10.1111/j.1469-7998.1995.tb02752.x

Croxall, J.P., \& Wood, A.G. (2002). The importance of the Patagonian Shelf for top predator species breeding at South Georgia. Aquatic Conservation: Marine and Freshwater Ecosystems, 12, 101-118. http://dx.doi.org/10.1002/aqc.480

Dauwe, T., Bervoets, L., Pinxten, R., Blust, R., \& Eens, M. (2003). Variation of heavy metals within and among feathers of birds of prey: effects of molt and external contamination. Environmental Pollution, 124, 429-436. http://dx.doi.org/10.1016/S0269-7491(03)00044-7

Eisler, R. (1986). Chromium hazards to fish, wildlife, and invertebrates: a synoptic review. U.S. Fish and Wildlife Service Biological Report 85 (1.6).

Favero, M., \& Silva Rodríguez, M.P. (2005). Estado actual y conservación de aves pelágicas que utilizan la plataforma continental Argentina como área de forrajeo. El Hornero, 20, 95-110.

Favero, M. (2008). South American perspective: fisheries mortality. In T. De Roy, M. Jones, \& J. Fitter (Eds.). Albatross: their world, their ways. (pp. 179-177). Auckland: David Bateman Ltd.

Furness, R.W., Muirhead, S.J., \& Woodburn, M. (1986). Using bird feathers to measure mercury in the environment: relationship between mercury content and moult. Marine Pollution Bulletin, 17, $27-37$. http://dx.doi.org/10.1016/0025-326X(86)90801-5

Furness, R.W. (1996). Cadmium in birds. In W.N. Beyer, S.H. Heinz, \& A.W. Redmon-Norwood (Eds.). Environmental contaminants in wildlife. (pp. 389-404). Boca Raton, Florida: Lewis Publishers.

Gandini, P.A., \& Frere, E. (2006). Spatial and temporal patterns in the bycatch of seabirds in the Argentinean longline fishery. Fisheries Bulletin, 104, 482-485.

González-Solís, J., Sampera, C., \& Ruiz, X. (2002). Metals and selenium as bioindicators of geographic and trophic segregation in Giant petrels Macronectes spp. Marine Ecology Progress Series, 244, $257-264$. http://dx.doi.org/10.3354/meps244257

Kim, E.Y., Goto, R., Tanabe, S., Tanaka, H., \& Tatsukawa, R. (1998). Distribution of 14 elements in tissues and organs of oceanic seabirds. Archives of Environmental Contamination and Toxicology, 35, 638-645. http://dx.doi.org/10.1007/s002449900426

Lacoue-Labarthe, T., Warnau, M., Oberhänsli, F., Teyssié, J.L., Jeffree, R., \& Bustamante, P. (2008). First experiments on the maternal transfer of metals in the cuttlefish Sepia officinalis. Marine Pollution Bulletin, 57, 826-831. http://dx.doi.org/10.1016/j.marpolbul.2008.01.042

Large Marine Ecosystems of the World (LME). (2011). Patagonian Shelf: Large Marine Ecosystem \# 14. [Online]

Available: http://www.lme.noaa.gov/index.php?option=com_content\&view=article\&id=60:1me14\&catid=41:briefs \&Itemid $=72($ September 2, 2011)

Lock, J.W., Thompson, D.R., Furness, R.W., \& Bartle, J.A. (1992). Metal concentrations in seabirds of the New Zealand regions. Environmental Pollution, 75, 289-300. http://dx.doi.org/10.1016/0269-7491(92)90129-X

Mackley, E.K., Phillips, R.A., Silk, J.R.D., Wakefield, E.D., Afanasyev, V., \& Furness, R.W. (2011). At-sea activity patterns of breeding and nonbreeding White-chined petrels Procellaria aequinoctialis from South Georgia. Marine Biology, 158, 429-438. http://dx.doi.org/10.1007/s00227-010-1570-x 
Marcovecchio, J., \& Ferrer, L. (2005). Distribution and geochemical partitioning of heavy metals in sediments of the Bahía Blanca Estuary, Argentina. Journal of Coastal Research, 21, 826-834. http://dx.doi.org/10.2112/014-NIS.1

Martin, A.R., Poncet, S., Barbraud, C., Foster, E., Fretwell, P., \& Rothery, P. (2009). The white-chinned petrel (Procellaria aequinoctialis) on South Georgia: population size, distribution and global significance. Polar Biology, 32, 655-661. http://dx.doi.org/10.1007/s00300-008-0570-5

Monteiro, L.R., \& Furness, R.W. (2001). Kinetics, dose-response, and excretion of methylmercury in free-living adult Cory's Shearwaters. Environmental Science and Technology, 35, 739-746. http://dx.doi.org/10.1021/es000114a

Monteiro, L.R., Granadeiro, J.P., \& Furness, R.W. (1998). Relationship between mercury levels and diet in Azores seabirds. Marine Ecology Progress Series, 166, 259-265. http://dx.doi.org/10.3354/meps166259

Muirhead, S.J., \& Furness, R.W. (1998). Heavy metals concentrations in the tissues of seabirds from Gough Island, South Atlantic Ocean. Marine Pollution Bulletin, 19, 278-283. http://dx.doi.org/10.1016/0025-326X(88)90599-1

Onley, D., \& Scofield, P. (2007). Albatrosses, petrels and shearwaters of the world. New Zealand: Princeton University Press.

Phillips, R.A., Silk, J.R.D., Croxall, J.P., \& Afanasyev, V. (2006). Year-round distribution of white-chinned petrels from South Georgia: relationships with oceanography and fisheries. Biological Conservation, 129, 336-347. http://dx.doi.org/10.1016/j.biocon.2005.10.046

Pilastro, A., Congiu, L., Tallandini, L., \& Turchetto, M. (1993). The use of bird feathers for the monitoring of cadmium pollution. Archives of Environmental Contamination and Toxicology, 24, 355-358. http://dx.doi.org/10.1007/BF01128733

Prince, P.A., \& Croxall, J.P. (1993). Birds of South Georgia: new records and re-evaluation of status. British Antarctic Survey Bulletin, 59, 15-27.

Quintana, F., Croxall, J.P., González-Solís, J., Phillips, R., Tratan, P., \& Falabella, V. (2009). Parte 3. Petreles. In V. Falabella, C. Campagna, \& J. Croxall (Eds.). Proyecto Modelo del Mar, Argentina (pp. 130-154). Wildlife Conservation Society, Argentina, CONICET, Argentina and BirdLife International, [Online] Available: http://atlas-marpatagonico.org/ (July 8, 2010).

R Development Core Team. (2008). R: a language and environment for statistical computing. R Foundation for Statistical Computing, Vienna, Austria. [Online] Available: http://www.R-project.org (January, 2008).

Seco Pon, J.P., Beltrame, O., Marcovecchio, J., Favero, M., \& Gandini, P. (2011). Trace metals (Cd, Cr, Cu, Fe, $\mathrm{Ni}, \mathrm{Pb}$, and $\mathrm{Zn}$ ) in feathers of Black-browed Albatross Thalassarche melanophrys attending the Patagonian Shelf. Marine Environmental Research, 72, 40-45. http://dx.doi.org/10.1016/j.marenvres.2011.04.004

Seco Pon, J.P., Gandini, P., \& Favero, M. (2007). Effect of longline configuration on the seabird mortality in the Argentine semi-pelagic Kingclip Genypterus blacodes fishery. Fisheries Research, 85, 101-105. http://dx.doi.org/10.1016/j.fishres.2007.01.002

Stewart, F.M., Phillips, R.A., Bartle, J.A., Craig, J., \& Shooter, D. (1999). Influence of phylogeny, diet, moult schedule and sex on heavy metal concentrations in New Zealand Procellariiformes. Marine Ecology Progress Series, 178, 295-305. http://dx.doi.org/10.3354/meps178295

Thompson, D.R., \& Furness, R.W. (1989a). Comparison of the levels of total and organic mercury in seabird feathers. Marine Pollution Bulletin, 20, 577-579. http://dx.doi.org/10.1016/0025-326X(89)90361-5

Thompson, D.R., \& Furness, R.W. (1989b). The chemical form of mercury stores in South Atlantic seabirds. Environmental Pollution, 60, 305-317. http://dx.doi.org/10.1016/0269-7491(89)90111-5

Towill, L.E., Shriner, C.R., Drury, J.S., Hammons, A.S., \& Holleman, J.W. (1978). Reviews of the environmental effects of pollutants: III Chromium. U.S. Environmental Protection Agency Report 600/1-78-023.

Warham, J. (1990). The Petrels: Their Ecology and Breeding Systems. London: Academic Press.

Zar, I. (1999). Biostatistical analysis. (3 rd ed.). Englewood Cliffs, New Jersey: Prentice-Hall Press. 
Table 1. Mean trace metal concentrations (in $\mu \mathrm{g} \mathrm{g}^{-1}$, dry mass) $\pm \mathrm{SD}$ in the last grown primary (P10) and breast feathers of adult White-chinned Petrel Procellaria aequinoctialis attending waters of the Patagonian Shelf, off Argentina in 2005. Geometric means are given in parentheses

\begin{tabular}{|c|c|c|c|c|}
\hline & \multicolumn{2}{|c|}{ Female $(n=21)$} & \multicolumn{2}{|c|}{ Male $(n=14)$} \\
\hline & Primary feather & Breast feathers & Primary feather & Breast feathers \\
\hline $\mathrm{Cd}$ & $<\operatorname{LOD}^{a}$ & $<\operatorname{LOD}^{a}$ & $<\operatorname{LOD}^{a}$ & $<\operatorname{LOD}^{a}$ \\
\hline $\mathrm{Cr}$ & $<\operatorname{LOD}^{a}$ & $\begin{array}{c}4.81 \pm 4.47 \\
(2.07)\end{array}$ & $<\operatorname{LOD}^{a}$ & $\begin{array}{c}7.03 \pm 4.98 \\
(3.99)\end{array}$ \\
\hline $\mathrm{Cu}$ & $\begin{array}{c}7.81 \pm 3.94 \\
(6.85)\end{array}$ & $\begin{array}{c}10.40 \pm 1.61 \\
(10.28)\end{array}$ & $\begin{array}{c}4.77 \pm 2.30 \\
\quad(4.21)\end{array}$ & $\begin{array}{c}10.78 \pm 2.56 \\
(10.55)\end{array}$ \\
\hline $\mathrm{Fe}$ & $\begin{array}{c}66.27 \pm 31.46 \\
(57.86)\end{array}$ & $\begin{array}{c}35.50 \pm 16.72 \\
(31.48)\end{array}$ & $\begin{array}{c}78.86 \pm 29.56 \\
(73.42)\end{array}$ & $\begin{array}{c}31.08 \pm 12.80 \\
(28.94)\end{array}$ \\
\hline $\mathrm{Pb}$ & $<\operatorname{LOD}^{a}$ & $<\operatorname{LOD}^{a}$ & $<\operatorname{LOD}^{a}$ & $<\operatorname{LOD}^{a}$ \\
\hline $\mathrm{Ni}$ & $<\operatorname{LOD}^{a}$ & $<\operatorname{LOD}^{a}$ & $<\operatorname{LOD}^{a}$ & $<\operatorname{LOD}^{a}$ \\
\hline $\mathrm{Zn}$ & $\begin{array}{c}74.57 \pm 18.32 \\
(72.49)\end{array}$ & $\begin{array}{c}84.19 \pm 18.59 \\
(82.41)\end{array}$ & $\begin{array}{c}77.39 \pm 17.63 \\
(75.65)\end{array}$ & $\begin{array}{c}70.67 \pm 21.85 \\
(67.91)\end{array}$ \\
\hline
\end{tabular}

Table 2. Average (arithmetic mean) trace metal concentrations ( $\mu \mathrm{g} \mathrm{g}^{-1}$, dry mass) in petrels' feathers reported in other studies (post-1997 publications only)

\begin{tabular}{|c|c|c|c|c|c|c|c|}
\hline Petrel species and location & $\mathrm{Cd}$ & $\mathrm{Cr}$ & $\mathrm{Cu}$ & $\mathrm{Fe}$ & $\mathrm{Pb}$ & $\mathrm{Zn}$ & Source \\
\hline \multicolumn{8}{|l|}{ Other petrels from the Southern Ocean } \\
\hline Northern Giant Petrel ( Macronectes halli ), GS/SG & 0.083 & $\mathrm{Na}$ & 6.211 & 103.719 & $<\operatorname{LOD}^{a}$ & 67.557 & Anderson et al. (2010) \\
\hline Southern Giant Petrel ( Macronectes giganteus ), GS/SG & 0.289 & $\mathrm{Na}$ & 6.877 & 95.208 & $<\mathrm{LOD}^{\mathrm{a}}$ & 90.208 & Anderson et al. (2010) \\
\hline White-chinned Petrel ( Procellaria aequinoctialis ), GS/SG & 0.138 & $\mathrm{Na}$ & 13.110 & 262.076 & $<\mathrm{LOD}^{\mathrm{a}}$ & 77.646 & Anderson et al. (2010) \\
\hline White-chinned Petrel ( Procellaria aequinoctialis), $\mathrm{SIO}^{\mathrm{b}}$ & 0.070 & $\mathrm{Na}$ & 10.400 & $\mathrm{Na}$ & 0.426 & 71.700 & Kim et al. (1998) \\
\hline White-chinned Petrel ( Procellaria aequinoctialis ), PS $^{c}$ & $<\mathrm{LOD}^{\mathrm{a}}$ & 2.070 & 10.410 & 30.210 & $<\mathrm{LOD}^{\mathrm{a}}$ & 75.160 & This study \\
\hline Common-diving Petrel ( Pelecanoides urinatrix ), GS/SG & 0.376 & $\mathrm{Na}$ & 31.254 & 130.911 & $<\mathrm{LOD}^{\mathrm{a}}$ & 301.098 & Anderson et al. (2010) \\
\hline South Georgia Diving-petrel ( Pelecanoides georgicus ), GS/SG & 0.300 & $\mathrm{Na}$ & 20.176 & 791.151 & $<\operatorname{LOD}^{\mathrm{a}}$ & 22.283 & Anderson et al. (2010) \\
\hline Antarctic Prion ( Pachyptila desolata ), GS/SG & 0.059 & $\mathrm{Na}$ & 20.176 & 1.010 .868 & $<$ LOD & 113.658 & Anderson et al. (2010) \\
\hline Blue Petrel ( Halobaena caerulea ), GS/SG & 0.074 & $\mathrm{Na}$ & 8.745 & 986.705 & $<\operatorname{LOD}^{\mathrm{a}}$ & 6.953 & Anderson et al. (2010) \\
\hline Flesh-footed Shearwater ( Puffinus carneipes ), AUS ${ }^{d}$ & 0.188 & $\mathrm{Na}$ & 14.005 & $\mathrm{Na}$ & 0.493 & 50.416 & Bond and Lavers (2010) \\
\hline Flesh-footed Shearwater ( Puffinus carneipes ), NZ ${ }^{d}$ & 0.065 & $\mathrm{Na}$ & 14.063 & $\mathrm{Na}$ & 0.419 & 96.115 & Bond and Lavers (2010) \\
\hline \multicolumn{8}{|l|}{ Other Procellariidae globally } \\
\hline Bonin Petrel ( Pterodroma hypoleuca ), NP & 0.104 & 1.580 & $\mathrm{Na}$ & $\mathrm{Na}$ & 0.926 & $\mathrm{Na}$ & Burger and Gochfeld (2000b) \\
\hline Wedge-tailed Shearwater ( Puffinus pacificus ), NP & 0.064 & 2.380 & $\mathrm{Na}$ & $\mathrm{Na}$ & 0.338 & $\mathrm{Na}$ & Burger and Gochfeld (2000b) \\
\hline Christmas Shearwater ( Puffinus nativitatis ), NP & 0.573 & 2.050 & $\mathrm{Na}$ & $\mathrm{Na}$ & 1.680 & $\mathrm{Na}$ & Burger and Gochfeld (2000b) \\
\hline
\end{tabular}

${ }^{a}<$ LOD below limit of detection; NA not analyzed.

${ }^{b}$ Black-browed Albatross, Grey-headed Albatross and White-chinned Petrel combined.

'Breast feathers of males and females combined.

$V$ alues reported in fresh mass.

GS/SG Georgias del Sur/South Georgia; SIO Southern Indian Ocean; PS Patagonian Shelf; AUS Australia; NZ New Zealand; NP North Pacific 


\begin{tabular}{|c|c|c|c|c|c|c|}
\hline & Sex & $n$ & Mean & S.D. & Range & $\mathrm{H}(P)$ \\
\hline \multirow[t]{2}{*}{ Upper bill length (cm) } & Female & 18 & 0.470 & 0.07 & $0.46-0.54$ & $6.327(0.012)$ \\
\hline & Male & 14 & 0.508 & 0.02 & $0.47-0.54$ & \\
\hline \multirow[t]{2}{*}{ Minimum bill depth $(\mathrm{cm})^{\mathrm{a}}$} & Female & 20 & 0.156 & 0.01 & $0.11-0.20$ & 1.609 (NS) \\
\hline & Male & 14 & 0.155 & 0.02 & $0.10-0.17$ & \\
\hline \multirow[t]{2}{*}{ Bill depth $(\mathrm{cm})^{b}$} & Female & 20 & 0.202 & 0.01 & $0.16-0.22$ & $7.366(0.011)$ \\
\hline & Male & 14 & 0.215 & 0.01 & $0.19-0.25$ & \\
\hline \multirow[t]{2}{*}{ Head width $(\mathrm{cm})$} & Female & 20 & 0.416 & 0.01 & $0.40-0.43$ & 2.009 (NS) \\
\hline & Male & 14 & 0.421 & 0.01 & $0.40-0.44$ & \\
\hline \multirow[t]{2}{*}{ Nape $(\mathrm{cm})$} & Female & 20 & 0.672 & 0.01 & $0.66-0.69$ & 1.313 (NS) \\
\hline & Male & 14 & 0.662 & 0.02 & $0.61-0.70$ & \\
\hline \multirow[t]{2}{*}{ Wing length $(\mathrm{cm})$} & Female & 21 & 70.557 & 4.73 & $65.2-89$ & 2.056 (NS) \\
\hline & Male & 14 & 68.371 & 3.04 & $63-73$ & \\
\hline \multirow[t]{2}{*}{ Tarsus lenght (cm) } & Female & 21 & 6.181 & 0.24 & $6-6.5$ & 1.145 (NS) \\
\hline & Male & 14 & 6.271 & 0.25 & $6-6.5$ & \\
\hline \multirow[t]{2}{*}{ Lenght of middle toe $(\mathrm{cm})$} & Female & 21 & 9.123 & 0.26 & $8.5-9.6$ & 1.444 (NS) \\
\hline & Male & 14 & 9.257 & 0.40 & $8.5-9.8$ & \\
\hline \multirow[t]{2}{*}{ Weight (g) } & Female & 21 & 1251.261 & 298.483 & $1150-1500$ & 2.442 (NS) \\
\hline & Male & 14 & 1383.928 & 151.151 & $1125-1625$ & \\
\hline
\end{tabular}

NS not significant.

${ }^{\text {a } M i n i m u m ~ d e p t h ~ a t ~ t h e ~ m i d ~ l e n g t h ~ o f ~ t h e ~ b i l l . ~}$

${ }^{b}$ Distance from the upper mandible to the lower mandible at the nostril.

Appendix A. Biometric data (mean $\pm \mathrm{SD}$ ) of adult White-chinned Petrel Procellaria aequinoctialis attending waters of the Patagonian Shelf, off Argentina. Kruskall-Wallis one-way ANOVA $(H)$ and probabilities $(P)$ are also given. 